\title{
Consumer Preferences for Fresh and Frozen Local Beef in Sleman Regency, Indonesia
}

\author{
Zuhud Rozaki ${ }^{1, *}$, Susanawati $^{1}$, Diah Rina Kamardiani ${ }^{1}$ and Arafahni Kartika Huda ${ }^{1}$ \\ ${ }^{1}$ Department of Agribusiness, Universitas Muhammadiyah Yogyakarta, 55183, Yogyakarta, \\ Indonesia
}

\begin{abstract}
This study aims to determine the consumer preferences for fresh and frozen local beef in Sleman Regency by employing a descriptive method. Meatshop Oricow, the biggest beef seller in Sleman Regency, was chosen purposively as the research location. A sample consisting of 50 fresh local beef consumers and 50 frozen local beef consumers were surveyed. Chi-Square analysis was utilized to determine the attributes of both fresh and frozen local beef. While the multi-attribute Fishbein analysis was used to determine consumers' attitudes toward both fresh and frozen local beef purchases. The results revealed that fairly cheap price, bright red meat color, fine fiber, practical packaging, less water content, low-fat content, and freshness were preferences of consumers in purchasing fresh and frozen local beef. Therefore, understanding consumer preferences can be the first step to develop the local beef market.
\end{abstract}

\section{Introduction}

Food insecurity is a standard part of developing countries and rural areas. At the level of food insecurity, food consumption focuses only on carbohydrate consumption. Although the consumption of carbohydrates has met nutritional needs, people should not only consume carbohydrates but also carbohydrate, protein, fat, and fiber. Indonesia's nutritional adequacy rate is divided by age and gender. Moreover, in the areas of low food insecurity or high food security, food consumption varies, not only carbohydrates, but they also consuming protein, fat and fiber.

Sleman is the largest rice-producing regency in the Special Region of Yogyakarta. However, the rate of food insecurity in the regency in the past few years was quite high, indicating that although production was abundant, it is not properly distributed among the population of the regency. Being in the condition of food insecurity, population consumption in this regency still focused on carbohydrates, because they cannot afford more than that. Nevertheless, in 2018, food security in this regency became better. The increasing of food security resulted in more varied food consumption trends. One of them is consuming fat from beef. The increasing number of beef buyers indicates an increase in the welfare or income of Sleman residents [1]. With the rise in beef consumption in this regency from year to year, food consumption also increasingly varies. Consumption is shifting away from cereal-based diet to a more diversified, protein-rich diet with emphasis on food quality, hygiene and safety,

* Corresponding author: zaki@umy.ac.id 
and eating more processed food [2].

The division of consumers is more on their welfare, not only on the shape and quality of the product. The increased welfare enhances the consumption of an item, where the quality and the nutrition contents of the item also becomes a consideration [3]. Currently, meat is a source of protein for humans, where the condition depends on the processing and how human treat it [4].

According to the Yogyakarta Food Security Agency [5], beef consumption in the Sleman Regency in 2015 was $0.61 \mathrm{~kg} /$ capita/year, while in 2016 , it rose to $0.63 \mathrm{~kg} / \mathrm{capita} /$ year. According to data released by the Director-General of Animal Husbandry and Animal Health at the Ministry of Agriculture, beef production in Indonesia in 2017 was 354,770 tons, while the estimated needs for beef reached 604,968 tons. Hence, encouraging the purchase of local meat is necessary to improve more the welfare of local breeders. Indeed, beef sellers also need to be encouraged to sell local meat. Therefore, the welfare of local breeders will increase and contribute to the rise of local meat production to meet the increasing needs of the community. Being unable to meet the needs of meat for the community, the production of local cattle needs more empowerment in the term of marketing, especially for small breeders [6].

The sale of local beef needs to be improved as it is safer than imported beef. The halalness of local beef is guaranteed as the slaughter process is carried out by local people who are Muslims and can be directly reviewed. On the contrary, imported beef should be first tested to meet the halalness provision before being sold. The creativity of local beef sellers increases from selling only fresh local beef to frozen local beef. Although frozen beef has the potential of protein oxidation in freezing for more than three months [7], community interest in purchasing this type of meat is quite high. However, they do not know the differences between fresh and frozen beef. They only consider that frozen beef will stay longer. This study aims to determine the preferences of the Sleman Regency residents for fresh or frozen beef. The results of this research can be used to develop beef production to meet community needs.

\section{Research Method}

This study employed a descriptive method to describe the preferences of consumers for fresh and frozen local beef. The research location chosen purposively was the largest local beef kiosk in Sleman Regency called Meatshop Oricow. In addition, this kiosk was creative in selling beef as it provided various variants of local beef, including sliced, minced, steak, rendang, ribs, and processed beef.

The sample determination utilized an convenience sampling technique, where consumers who bought fresh or frozen beef when the sampling was carried out were chosen as the respondents. More specifically, these respondents taken were married women as they considered more often purchasing beef for family needs. The number of respondents was 100 consumers, consisting of 50 fresh local beef consumers and 50 frozen local beef consumers. The research was carried out from 26 February to 14 March 2019.

Chi-Square analysis was used to discover the attributes of consumer preferences for fresh and frozen local beef, with the following formula: 


$$
x^{2}=\sum_{i=1}^{\mathrm{k}}\left(\frac{(f o-f h)^{2}}{f h}\right)
$$

Description:

$\mathrm{x} 2=$ Chi-Square

fo $\quad=$ frequency of observations

fh $\quad=$ expected frequency

$\mathrm{i} . . . \mathrm{k}=$ attribute category in the beef variable at the Meatshop Oricow

Furthermore, Fishbein analysis was employed to determine the most considered attribute in purchasing fresh and frozen local beef, with the following formula:

$$
A_{o}=\sum_{i=l}^{n} b i . e i
$$

Description:

A0 = consumers' attitudes towards fresh and frozen local beef at the Meatshop Oricow

bi = the level of consumers' trust that beef purchased has a certain variable

ei = consumer evaluation of the to-i variable of fresh and frozen beef at the Meatshop Oricow

$\mathrm{n} \quad=$ the number of attributes the object has

$\mathrm{i} \quad=$ attributes $(\mathrm{i}=1,2,3 \ldots \mathrm{n})$

Procedures:

First, determining the assessment of trust in beef attributes (bi) using the following Likert scale: (1) bad, (2) poor, (3) fair, (4) good, (5) excellent. The value of trust in beef was obtained by dividing the number of respondents' answers by the number of respondents, as presented in the following formula:

$$
\mathrm{bi}=\frac{5 a+4 b+3 c+2 d+e}{a+b+c+d+e}
$$

Description:

bi : value of trust in beef

$a:$ number of respondents choosing excellent $b:$ number of respondents choosing good

$\mathrm{c}$ : number of respondents choosing fair $\mathrm{d}$ : number of respondents choosing poor

e : number of respondents choosing bad

Second, determining the evaluation of the attributes using the following Likert scale: (1) very unimportant, (2) unimportant, (3) moderately important, (4) important, (5) very important. Then the score of each attribute was multiplied by the frequency of respondents' answers to obtain the value of consumer evaluation of beef attributes.

In determining the dominant attributes considered by consumers, the consumer attitude index was sorted from the highest to the lowest value. Consumers' attitudes were obtained by multiplying trust scores by trust scores.

\section{Results and Discussion}

\subsection{Characteristic of Consumers}

In general, the characteristics of consumers affect their preferences in buying goods [8]. 


\subsubsection{Age}

At these ages, many young homemakers chose to buy fresh beef and frozen beef due to the high nutritional content and the needs of their family for meat protein intake. Therefore, it indicates an increase in awareness of the consumption of animal protein in the younger generation.

\subsubsection{Education}

The majority of respondents had a bachelor's degree. Specifically, 54\% of fresh beef consumers and $58 \%$ of frozen beef consumers were scholars. It shows that highly educated consumers having different mindsets and types of preferences from low educated people. In addition, those highly educated consumers tend to be more aware of nutritional needs; in this case, the need for protein from local beef.

Table 1. Characteristics of Fresh and Frozen Local Beef Consumers

\begin{tabular}{|c|c|c|c|c|c|}
\hline \multirow{2}{*}{ Consumer Characteristics } & \multicolumn{2}{|c|}{ Fresh Local Beef } & \multicolumn{2}{|c|}{ Frozen Local Beef } & \multirow[t]{2}{*}{ Freq. } \\
\hline & Freq. & Percent & Freq. & Percent & \\
\hline \multicolumn{6}{|l|}{ Age (year) } \\
\hline $24-34$ & 22 & 44 & 32 & 64 & 54 \\
\hline $35-44$ & 18 & 36 & 18 & 36 & 36 \\
\hline $45-54$ & 9 & 18 & - & - & 9 \\
\hline $55-64$ & 1 & 2 & - & - & 1 \\
\hline Total & 50 & 100 & 50 & 100 & 100 \\
\hline \multicolumn{6}{|l|}{ Education Level } \\
\hline Senior high school & 13 & 26 & 12 & 24 & 25 \\
\hline Diploma 1 & 1 & 2 & 1 & 2 & 2 \\
\hline Diploma 3 & 3 & 6 & 5 & 10 & 8 \\
\hline Bachelor & 27 & 54 & 29 & 58 & 56 \\
\hline Master & 6 & 12 & 3 & 6 & 9 \\
\hline Total & 50 & 100 & 50 & 100 & 100 \\
\hline \multicolumn{6}{|l|}{ Occupation } \\
\hline Housewife & 13 & 26 & 14 & 28 & 27 \\
\hline Entrepreneur & 17 & 34 & 13 & 26 & 30 \\
\hline Midwife & 1 & 2 & - & - & 1 \\
\hline General employee & 5 & 10 & 7 & 14 & 12 \\
\hline Civil servant & 6 & 12 & 9 & 18 & 15 \\
\hline Teacher & 1 & 2 & 3 & 6 & 4 \\
\hline Nurse & 5 & 10 & 2 & 4 & 7 \\
\hline Lecturer & 2 & 4 & 1 & 2 & 3 \\
\hline Policewoman & - & - & 1 & 2 & 1 \\
\hline Total & 50 & 100 & 50 & 100 & 100 \\
\hline \multicolumn{6}{|l|}{ Income (IDR) } \\
\hline$<1,000,000$ & 1 & 2 & - & - & 1 \\
\hline $1,000,000-2,999,999$ & 27 & 54 & 25 & 50 & 52 \\
\hline $3,000,000-4,999,999$ & 18 & 36 & 23 & 46 & 41 \\
\hline $7,000,000-8,999,999$ & 4 & 8 & 2 & 4 & 6 \\
\hline Total & 50 & 100 & 50 & 100 & 100 \\
\hline \multicolumn{6}{|l|}{ Number of family members } \\
\hline $2-4$ & 35 & 70 & 42 & 84 & 77 \\
\hline $5-7$ & 15 & 30 & 8 & 16 & 23 \\
\hline Total & 50 & 100 & 50 & 100 & 100 \\
\hline
\end{tabular}




\subsubsection{Occupation}

In terms of occupation, the entrepreneur dominates consumers of both fresh and frozen local beef in Sleman Regency. As the fresh local beef stock was available more in the morning, it was easier for entrepreneurs to buy this type of beef due to their flexible work time. Meanwhile, housewifes are in second place because of their role, making them free to choose the diet for the family. Their choice of both fresh and frozen illustrates their awareness to meet the needs of animal protein for the family.

\subsubsection{Income}

In terms of income, most of the respondents' income ranged between IDR 1,000,000 to $2,999,999$. Despite their relatively low income, they still bought the beef, one of the reason might be their high awareness of animal protein needs.

\subsubsection{Number of Family Members}

The majority of respondents in this study had 2-4 family members. The number of family members might underlie the effort to meet the animal protein needs by purchasing both fresh and frozen local beef. And might be because it is expensive to buy for family of 5-7 people.

\subsection{Consumers Purchase Behaviour}

\subsubsection{Purchase Reasons}

Table 2 shows the variety of customers' reasons for purchasing fresh and frozen local beef. Beef variants' completeness dominates the reasons for buying both types of meat. The variants of fresh local beef refer to various parts of the body of the cattle. Moreover, consumers could freely ask for cut according to their preferences. While frozen beef variants are neatly packaged beef with various sizes, cuts, and prices. In addition, the reason underlying the purchase of fresh local beef is the fresher and newer condition of the meat. The halalness of the product also became one of the reasons for purchasing local beef, considering the majority of people in Sleman are Muslims.

\subsubsection{Purchase Frequency}

As presented in Table 2, consumers had specific frequencies in purchasing both fresh and frozen local beef. The highest frequency of fresh local beef purchase is uncertain (38\%), followed by once every two weeks $(32 \%)$, once a week $(24 \%)$, and only a few consumers purchasing this type of beef every day $(6 \%)$. The frequencies of purchasing frozen local beef are similar to fresh local beef in which the highest frequency is also uncertain $(36 \%)$, followed once a week (40\%), once every two weeks $(22 \%)$ and every day $(2 \%)$.

\subsubsection{Purchase Amount}

Most respondents (76\%) purchased fresh local beef of less than $1 \mathrm{~kg}$. Some others $(24 \%)$ bought 1-2 kg of beef. Moreover, considering the tendency of this type of beef being cooked immediately instead of stored, there was no respondent bought this beef in the amount of more than $2 \mathrm{~kg}$. It underlies the small purchases of fresh local beef. The same similar results 
also applied to frozen local beef purchases, in which the majority of respondents $(88 \%)$ bought less than $1 \mathrm{~kg}$ of meat. It was considered the most appropriate amount to meet the needs of meat consumption in a day or two days. However, given that frozen meat is more likely to be stored first, a number of respondents (2\%) appeared to have bought this type of beef of more than $2 \mathrm{~kg}$. Some of these purchases were cooked directly, while the rest would be stored as stock.

Table 2. Purchase Behavior of Fresh and Frozen Local Beef Consumers

\begin{tabular}{|c|c|c|c|c|c|}
\hline \multirow[b]{2}{*}{ Purchase Behavior } & \multicolumn{2}{|c|}{ Fresh Beef } & \multicolumn{2}{|c|}{ Frozen Beef } & \multirow{2}{*}{$\begin{array}{c}\text { Total } \\
\text { (people) }\end{array}$} \\
\hline & $\begin{array}{c}\text { Total } \\
\text { (people) }\end{array}$ & $\begin{array}{l}\text { Percentage } \\
(\%)\end{array}$ & $\begin{array}{c}\text { Total } \\
\text { (people) }\end{array}$ & $\begin{array}{c}\text { Percentage } \\
(\%)\end{array}$ & \\
\hline \multicolumn{6}{|l|}{$\begin{array}{l}\text { Purchase Reasons (could be more } \\
\text { than one) }\end{array}$} \\
\hline Fresh beef & 7 & 10,8 & 2 & 3,4 & 9 \\
\hline Always-new beef & 5 & 7,7 & 4 & 6,8 & 9 \\
\hline Beef quality & 6 & 9,2 & 4 & 6,8 & 10 \\
\hline Beef variants completeness & 9 & 13,8 & 14 & 23,7 & 23 \\
\hline Halal guaranteed & 8 & 12,3 & 6 & 10,2 & 14 \\
\hline Supermarket-like concept & 6 & 9,2 & 1 & 1,7 & 7 \\
\hline Near place & 4 & 6,2 & 5 & 8,5 & 9 \\
\hline Clean place & 8 & 12,3 & 11 & 18,6 & 19 \\
\hline Healthier beef & 1 & 1,5 & - & - & 1 \\
\hline Friendly employees & 4 & 6,2 & 4 & 6,8 & 8 \\
\hline Open until evening & 1 & 1,5 & 3 & 5,1 & 4 \\
\hline Crowded place & - & - & 1 & 1,7 & 1 \\
\hline $\begin{array}{l}\text { Comfortable and recommended } \\
\text { place }\end{array}$ & 2 & 3,1 & 2 & 3,4 & 4 \\
\hline Attractive & 2 & 3,1 & - & - & 2 \\
\hline Practical & 1 & 1,5 & - & - & 1 \\
\hline Neat packaging & 1 & 1,5 & 1 & 1,7 & 1 \\
\hline Subscribe & - & - & 1 & 1,7 & 1 \\
\hline Total & 65 & 100 & 59 & 100 & 124 \\
\hline \multicolumn{6}{|l|}{ Purchase Frequency } \\
\hline Every day & 3 & 6 & 1 & 2 & 4 \\
\hline Once a week & 12 & 24 & 20 & 40 & 32 \\
\hline Once every two weeks & 16 & 32 & 11 & 22 & 27 \\
\hline Uncertain & 19 & 38 & 18 & 36 & 37 \\
\hline Total & 50 & 100 & 50 & 100 & 100 \\
\hline \multicolumn{6}{|l|}{ Purchase Amount (kg) } \\
\hline$<1$ & 38 & 76 & 44 & 88 & 82 \\
\hline $1-2$ & 12 & 24 & 5 & 10 & 17 \\
\hline$>2$ & - & - & 1 & 2 & 1 \\
\hline Total & 50 & 100 & 50 & 100 & 100 \\
\hline \multicolumn{6}{|l|}{ Other Products Purchase } \\
\hline Sausage & 5 & 11,9 & 5 & 11,4 & 10 \\
\hline Meatballs & 8 & 19,0 & 10 & 22,7 & 18 \\
\hline Roulade and galantine & 9 & 21,4 & 6 & 13,6 & 15 \\
\hline Beef floss & 7 & 16,7 & 7 & 15,9 & 14 \\
\hline Character meatballs (suki) & 6 & 14,3 & 8 & 18,2 & 14 \\
\hline Instant seasoning & 7 & 16,7 & 8 & 18,2 & 15 \\
\hline Total & 50 & 100 & 50 & 100 & 100 \\
\hline
\end{tabular}




\subsubsection{Other Product Purchase}

In addition to fresh and frozen local beef, respondents also purchased other beef products sold at the Meatshop Oricow, such as meatballs, sausages, beef floss, and other traditional foods (see Table 2). The purchases of these products were intended to increase the variety of beef consumed. It also aimed to facilitate the cooking process due to their practicality. These other products are processed beef requiring less effort to cook.

\subsection{Consumer Preferences}

\subsubsection{Fresh Local Beef Attributes}

In choosing the beef product purchased, consumers usually considered several aspects such as price, hygiene, the condition of the beef, and type of beef [8-10]. The price, color, and freshness attributes of fresh local beef at the Meatshop Oricow were significant at the $99 \%$ trust level. It means that there are differences in consumer preferences regarding price, color, and freshness. Consumers preferred affordable price beef, starting from IDR 32,000 per 250 gram. Beef price also depended on the number of consumers purchasing the fresh local beef; the lower price, the more buyers.

Regarding color, fresh local beef consumers preferred bright red color beef, indicating the freshness of the meat. In terms of freshness, consumers preferred the freshest local beef placed in the display window of the kiosk. In short, the freshness factor became the primary preference in purchasing fresh local beef. The fiber, fat content, and packaging attributes in fresh local beef had a significance level at 0.05 , indicating some differences in consumer preferences. Fine-fiber beef became a consumer preference due to its ease of cooking. As consuming excessive fat is bad for the body, low-fat content was also another consumer preference. Consumers preferred products having more nutrition [3]. The packaging was also one of the attributes becoming consumer preferences, in which excellent and attractive packaging was popular for consumers. Specifically, the most attractive packaging was practical and simple ones due to its economic aspect. Furthermore, the water content attribute did not show a significant value, resulting in it not being one of the consumer preferences in purchasing fresh local beef.

Table 3. Analysis Results of Fresh Local Beef Attributes at the Meatshop Oricow

\begin{tabular}{|l|c|c|}
\hline \multicolumn{1}{|c|}{ Attribute } & Chi-Square Value & Signification \\
\hline Price & $17,920^{* * *}$ & .000 \\
\hline Color & $16,120^{* * *}$ & .000 \\
\hline Fiber & $5,120^{* *}$ & .024 \\
\hline Packaging & $2,880^{* *}$ & .090 \\
\hline Water content & 1,280 & .258 \\
\hline Fat content & $7,000^{* *}$ & .030 \\
\hline Freshness & $9.680^{* * *}$ & .002 \\
\hline
\end{tabular}

$* * *$ Significant at 0.01 level

**Significant at 0.05 level

\subsubsection{Frozen Local Beef Attributes}

Table 4 illustrates that the price, color, packaging, fat content, and freshness attributes of frozen local beef were significant at the 0.01 level. It means that there were differences in 
consumer preferences for frozen local beef attributes. Furthermore, there were several advantages of purchasing frozen beef; for example, it could last longer compared to the fresh beef and reduce microorganisms. However, in terms of packaging, it often does not meet the standards for maintaining frozen beef quality [11].

Table 4. Analysis Results of Frozen Local Beef Attributes at the Meatshop Oricow

\begin{tabular}{|l|c|c|}
\hline Attribute & Chi-Square Value & $\begin{array}{c}\text { Significatio } \\
\text { n }\end{array}$ \\
\hline Price & $49.480^{* *}$ & .000 \\
\hline Color & $21.200^{* *}$ & .043 \\
\hline Fiber & $6.480^{*}$ & .011 \\
\hline Packaging & $27.160^{* *}$ & .000 \\
\hline Water content & $3.920^{*}$ & .048 \\
\hline Fat content & $15.520^{* *}$ & .000 \\
\hline Freshness & $11.520^{* *}$ & .001 \\
\hline
\end{tabular}

**Significant at 0.01 level

*Significant at 0.05 level

In terms of price, frozen local beef consumers preferred fairly cheap meat with price ranging from IDR 32,000 to 37,000 per 250 gr. Consumers were willing to spend more money to buy frozen local beef due to its excellent protein content and quality. Consumers preferred bright red beef as it looked fresher (See Table 5). Moreover, practical packaging became one of the customer preferences, considering that it was more economical and easily stored in the freezer. Furthermore, they preferred low-fat beef because it was healthier than high-fat beef. Regarding freshness, consumers chose fresher frozen meat, meaning that the meat had been recently frozen.

Fiber and water content attributes were significant at level 0.05 . Meat fiber became a consideration in the purchase and consumption of beef. In this case, fine fiber beef was more attractive to buy, with the consideration easier to consume and that the seasonings were easily absorbed. Meanwhile, in terms of water content, the less-water content, the more attractive the meat. Highly-water-content beef tends to have less fiber and protein content.

The total amount of consumer trust in fresh and frozen local beef belonged to the good category, more specifically 25.04 and 24.48, respectively (See Table 6). However, viewing from each attribute, the highest score was in the attributes of fresh beef, particularly the freshness aspect included in the excellent category. The results of consumer trust in frozen local beef show similar findings, in which the freshness attribute became the most believed one. Although frozen, beef freshness should also be considered such as from the color. There are several differences in consumer trust in the fiber attribute of fresh and frozen local beef. The results revealed that this attribute belonged to the good category for fresh beef, but neutral for frozen beef due to changes in fiber. 
Table 5. Consumer Preferences on the Attribute Categories of Fresh and Frozen Local Beef

\begin{tabular}{|c|c|c|c|}
\hline \multirow{2}{*}{ Attribute } & \multirow[t]{2}{*}{ Category (preference) } & $\begin{array}{c}\text { Fresh Local } \\
\text { Beef }\end{array}$ & $\begin{array}{c}\text { Frozen Local } \\
\text { Beef }\end{array}$ \\
\hline & & $\begin{array}{c}\text { Total } \\
\text { (people) }\end{array}$ & $\begin{array}{c}\text { Total } \\
\text { (people) }\end{array}$ \\
\hline \multirow[t]{5}{*}{ Price } & Very cheap & - & - \\
\hline & Cheap & 6 & 3 \\
\hline & \begin{tabular}{|l} 
Cheap enough \\
\end{tabular} & 30 & 40 \\
\hline & Expensive & 14 & 7 \\
\hline & Very expensive & - & - \\
\hline \multirow[t]{4}{*}{ Color } & Brownish red & - & 1 \\
\hline & Heart red & 11 & 13 \\
\hline & Bright red & 30 & 24 \\
\hline & \begin{tabular}{|l|} 
Pink \\
\end{tabular} & 9 & 12 \\
\hline \multirow[t]{2}{*}{ Fiber } & Rough & 17 & 16 \\
\hline & Fine & 33 & 34 \\
\hline \multirow[t]{3}{*}{ Packaging } & Unattractive & - & 1 \\
\hline & Attractive & 31 & 31 \\
\hline & Very attractive & 19 & 18 \\
\hline \multirow[t]{3}{*}{ Water content } & \begin{tabular}{|l|} 
High \\
\end{tabular} & - & - \\
\hline & Moderate & 21 & 18 \\
\hline & Low & 29 & 32 \\
\hline \multirow[t]{3}{*}{ Fat content } & High & 10 & 4 \\
\hline & Low & 15 & 26 \\
\hline & Without fat & 25 & 20 \\
\hline \multirow[t]{3}{*}{ Freshness } & Not fresh & - & - \\
\hline & Fresh & 14 & 37 \\
\hline & Very fresh & 36 & 13 \\
\hline
\end{tabular}

Table 6. Consumer Trust in Fresh and Frozen Local Beef Attributes

\begin{tabular}{|l|c|l|c|l|}
\hline \multirow{2}{*}{ Attribute } & \multicolumn{2}{|c|}{ Fresh Beef } & \multicolumn{2}{c|}{ Frozen Beef } \\
\cline { 2 - 5 } & Trust & Category & Trust & \multicolumn{1}{c|}{ Category } \\
\hline Price & 3.72 & Good & 3.64 & Good \\
\hline Color & 3.80 & Good & 3.66 & Good \\
\hline Fiber & 3.46 & Good & 3.22 & Fair \\
\hline Packaging & 3.52 & Good & 3.50 & Good \\
\hline Water content & 2.96 & Fair & 3.06 & Fair \\
\hline Fat content & 3.20 & Fair & 3.24 & Fair \\
\hline Freshness & 4.38 & Excellent & 4.16 & Excellent \\
\hline Total & 25.04 & Good & 24.48 & Good \\
\hline
\end{tabular}


Table 7. Consumer Evaluation of Fresh and Frozen Local Beef Attributes

\begin{tabular}{|l|c|l|l|l|}
\hline \multirow{2}{*}{ Attribute } & \multicolumn{2}{|c|}{ Fresh Local Beef } & \multicolumn{2}{l|}{ Frozen Local Beef } \\
\cline { 2 - 5 } & Evaluation & Category & Evaluation & Category \\
\hline Price & 3.78 & Important & 3.66 & Important \\
\hline Color & 3.92 & Important & 3.98 & Important \\
\hline Fiber & 3.34 & $\begin{array}{l}\text { Moderately } \\
\text { important }\end{array}$ & 3.26 & $\begin{array}{l}\text { Moderately } \\
\text { important }\end{array}$ \\
\hline Packaging & 3.54 & Important & 3.68 & Important \\
\hline $\begin{array}{l}\text { Water } \\
\text { content }\end{array}$ & 2.74 & $\begin{array}{l}\text { Moderately } \\
\text { important }\end{array}$ & 2.92 & $\begin{array}{l}\text { Moderately } \\
\text { important }\end{array}$ \\
\hline $\begin{array}{l}\text { Fat } \\
\text { content }\end{array}$ & 3.08 & $\begin{array}{l}\text { Moderately } \\
\text { important }\end{array}$ & 3.22 & $\begin{array}{l}\text { Moderately } \\
\text { important }\end{array}$ \\
\hline Freshness & 4.46 & Very important & 4.30 & Very important \\
\hline
\end{tabular}

Of the seven attributes, only freshness belonged to the very important category, both for fresh and frozen local beef (see Table 7). These findings support the result of customer preferences, in which freshness was the most trusted and considered aspect of purchasing both types of beef. While price, color, and packaging belonged to an important category. Today's consumers tend to consider that food safety, environment, and quality are important. Moreover, the price also affected consumers' willingness to buy beef, especially for lowermiddle economy consumers [12-14].

Table 8. Consumer Attitude of Fresh and Frozen Local Beef Attributes

\begin{tabular}{|l|c|c|c|c|}
\hline \multirow{2}{*}{ Attribute } & \multicolumn{2}{|c|}{ Fresh Local Beef } & \multicolumn{2}{c|}{ Frozen Local Beef } \\
\cline { 2 - 5 } & Attitude & Category & Attitude & Category \\
\hline Price & 14.06 & Fair & 13.32 & Fair \\
\hline Color & 14.90 & Fair & 14.57 & Fair \\
\hline Fiber & 11.56 & Fair & 10.50 & Poor \\
\hline Packaging & 12.46 & Fair & 12.88 & Fair \\
\hline Water content & 8.11 & Poor & 8.94 & Poor \\
\hline Fat content & 9.86 & Poor & 10.43 & Poor \\
\hline Freshness & 19.53 & Good & 17.89 & Good \\
\hline
\end{tabular}

Consumers' assessment of beef was not only limited to its physical aspects but also involved buyers' emotional side. The physicality of frozen beef was able to lure customers. Furthermore, as stressed by [15-18], attractive promotions could also increase buyers' interest in purchasing a product. The attitude of consumers being in a good category was just the freshness attribute of both fresh and frozen local beef. This attitude determines how consumers choose what they want to buy. While the price, color, and packaging belonged to the neutral category. Fiber attribute for fresh local beef was in the neutral category but belonged to the bad category for frozen local beef. Both water and fat content in beef were classified as poor. It means consumers preferred fresh and frozen local beef having less water and fat content. In addition, they were afraid of the person who injected water into cattle to make it more substantial.

Research by [19] asserts that the driving forces of consumers to buy beef were based on meat quality, consumer preferences, willingness to purchase, ease purchasing, and packaging. Moreover, research conducted by [20] revealed that consumer preferences for both fresh local beef did not differ significantly from frozen beef. 


\section{Conclusion}

In a word, consumer preferences in purchasing fresh and frozen local beef were the same: fairly cheap price, bright red color beef, fine fiber, practical packaging, water-low meat, lowfat meat, and fresh meat. The freshness attribute became an important point to consider in purchasing these two types of beef, shown by the high level of consumer trust and good consumer attitudes. In a nutshell, efforts to increase sales and consumption could be started by paying attention to consumer preferences for both fresh and frozen local beef.

\section{References}

1. E. Prifti, African J. Agric. Resour. Econ. 12, 52 (2017).

2. ASEAN, Strategic Plan Of Action For Asean Cooperation On Forestry. https://asean.org/storage/2016/10/Strategic-Plan-of-Action-for-ASEAN-Cooperationon-Forestry-2016-2025.pdf (2016).

3. C. Wanjuu, T. Bocher, G. Abong', J. Low, D. Mbogo, S. Heck, and T. Muzhingi, Open Agric. 4, 616 (2019).

4. M. Font-i-furnols and L. Guerrero, Meat Sci. 98, 361 (2014).

5. Badan Ketahanan Pangan DIY, Data Konsumsi Bahan Pangan Daerah Istimewa Yogyakarta (Food Consumption in Special Region of Yogyakarta) (2015).

6. A. Agus, T. Satya, and M. Widi, Asian-Australian J. Anim. Sci. 31, 976 (2018).

7. A. Soyer, B. Özalp, Ü. Dalmis, and V. Bilgin, Food Chem. 120, 1025 (2010).

8. V. M. Merlino, D. Borra, V. Girgenti, A. Dal Vecchio, and S. Massaglia, Meat Sci. 143, 119 (2018).

9. C. Apostolidis and F. McLeay, Food Qual. Prefer. 77, 109 (2019).

10. M. S. Lambooij, J. Veldwijk, P. van Gils, M. J. J. Mangen, E. Over, A. Suijkerbuijk, J. Polder, G. A. de Wit, and M. Opsteegh, Meat Sci. 149, 1 (2019).

11. F. W. M. Damen and L. P. A. Steenbekkers, Br. Food J. 109, 511 (2007).

12. P. O'Donovan and M. McCarthy, Br. Food J. 104, 353 (2002).

13. C. A. Bisschoff, J. Contemp. Manag. 14, 554 (2017).

14. P. Udomkun, J. Ilukor, J. Mockshell, G. Mujawamariya, C. Okafor, R. Bullock, N. Léon, and N. Bernard, Food Sci. Nutr. 2321 (2018).

15. S. Alessandro and S. Luisa, IERI Procedia 8, 52 (2014).

16. Widodo, S. Y. Rusimah, and N. Choirunisa, AGRARIS: Journal of Agribusiness and Rural Development Research 4, 1 (2018).

17. Widodo, D. R. Kamardiani, and L. Rahayu, AGRARIS: Journal of Agribusiness and Rural Development Research 2, 2 (2016)

18. A. N. Fadilah, Widodo and A. S. Widodo, AGRARIS: Journal of Agribusiness and Rural Development Research 1, 2 (2015)

19. P. Uys and C. Bisschoff, Probl. Ad Perspect. Manag. 14, 256 (2017).

20. P. Qing, A. Xi, and W. Hu, Emerg. Mark. Financ. Trade 50, 135 (2016). 